\title{
Optimizing functional properties of perilla protein isolate using the response surface methodology
}

\author{
Dongliang $\mathrm{HE}^{1,2}$, Zhijun ZHANG ${ }^{1 *}$, Huizhen $\mathrm{LI}^{1}$, Yaoyao XIA${ }^{1}$, Xiaojun $\mathrm{LI}^{1}$, Tie CHEN ${ }^{1}$
}

\begin{abstract}
Response surface methodology (RSM) was used to optimize the ultrasound-assisted extraction parameters of perilla protein isolate (PPI), which has functional properties. A central composite experimental design was applied to investigate the effects of three factors (ultrasonic power, extraction time, and liquid-to-solid ratio) on six responses: protein yield, water solubility index (WSI), water absorption capacity (WAC), oil holding capacity (OHC), emulsifying activity (EA), and foaming ability (FA). Based on the RSM results, the optimum conditions were an ultrasonic power of $206 \mathrm{~W}$, and extraction time of $32.4 \mathrm{~min}$, and a liquid-to-solid ratio of 10.34:1. Under these conditions, PPI had high protein yield (26.1\%) and functional properties (55.2\% WSI, 3.6\% WAC, $1.76 \mathrm{~g} / \mathrm{g}$ OHC, $60.25 \mathrm{~m}^{2} / \mathrm{g}$ EA, 63.2\% FA). Differential scanning calorimetry revealed that PPI was slightly denatured at $75.16^{\circ} \mathrm{C}$, and the amount of heat required to induce this denaturation was $0.03 \mathrm{~J} / \mathrm{g}$. SDS-PAGE presented protein bands that ranged from 14.4 to $66.2 \mathrm{kDa}$. Based on its functional properties, PPI can be used in the food industry.
\end{abstract}

Keywords: ultrasound-assisted extraction; perilla protein isolate; protein yield; functional properties; thermal stability; polypeptide profile.

Practical Application: Based on its thermal stability and functional properties, the ultrasound-assisted extracted perilla protein isolate would be suitable as high quality edible protein and could be applied in food industries.

\section{Introduction}

With increasing consumer concerns over protein shortage, there has been a considerable interest on unconventional proteins isolated from plant sources. Perilla (Perilla frutescens L), an annual edible herb, is used for cooking and medicinal purposes in several Asian countries, such as China, Japan, and Korea (Asif, 2011). Perilla seed consists of $51.7 \%$ fat and $17.0 \%$ protein (Longvah \& Deosthale, 1991), and defatted perilla seed meal consists of $\sim 40 \%$ protein (Longvah \& Deosthale, 1998). In spite of being an important protein source, defatted perilla seed meal is mainly used as animal feed and fertilizer. The use of perilla seed meal as a value-added food ingredient is worth exploring. Perilla protein, especially perilla protein isolate (PPI), has several high functional properties such as water solubility index, water absorption capacity, oil holding capacity, emulsifying activity, and foaming ability, which could expand its applications in the food industry.

Chemical and enzymatic modifications have been used to improve the functional properties of plant proteins. However, these modification methods, which may contribute to toxic by-products, tend to be expensive in large-scale industrial applications. Ultrasonic extraction, which has gained increasing popularity, can be used in conjunction with, or in place of, traditional extraction methods because of its reduced extraction times and cost-effectiveness (Luque-García \& Castro, 2003). Ultrasound-assisted extraction contributes to high extraction yield and is easily adapted to large-scale industrial applications (Vinatoru, 2001). Our previous findings revealed that the most influential parameters affecting protein content and protein yield were ultrasonic power, extraction time, and liquid-to-solid ratio. The optimization of these parameters could be achieved with response surface methodology (RSM).

RSM is an effective statistical technique for optimizing experimental protocols. RSM evaluates the effects of multiple factors and their interactions on one or more response variables (Azmir et al., 2014; Karnopp et al., 2015; Xu et al., 2013). An advantage of RSM is that it reduces the number of experiments and provides a mathematical model.

In this study, RSM was applied to study the effects of ultrasonic power, extraction time, and liquid-to-solid ratio on PPI yield and functional properties including its water solubility index, water absorption capacity, oil holding capacity, emulsifying activity, and foaming ability. Additionally, the thermal properties and polypeptide profile of PPI were analyzed.

\section{Materials and Methods}

\subsection{Sample preparation and chemicals}

Fresh whole perilla seeds were collected in October 2015 from North University of China (Taiyuan, Shanxi Province, China). The seeds were dried in an air convection oven at 
$50{ }^{\circ} \mathrm{C}$ for $72 \mathrm{~h}$, dehulled, and ground into flour. The flour was defatted in a Soxhlet extraction apparatus using $n$-hexane as the organic solvent. Defatted flour was spread on a plate for $4 \mathrm{~h}$ at room temperature under a laboratory fume hood to remove any traces of the solvent. Subsequently, the flour was passed through a 60 -mesh size screen, packaged in polyethylene bags, and stored at $5{ }^{\circ} \mathrm{C}$ until use.

Commercial soy protein isolate (SPI), supplied by Sino Peptide Health Technology Co, Ltd (Beijing, China), was used for comparisons. All chemicals used in this study were of analytical grade and were purchased from Beijing Chemicals Co. (Beijing, China).

\subsection{Experimental design}

A Central Composite Design (CCD) consisting of the independent variables $\mathrm{x}_{1}$ (ultrasonic power), $\mathrm{x}_{2}$ (extraction time), and $\mathrm{x}_{3}$ (liquid-to-solid ratio) at five different levels was used to study the response pattern and determine the optimum combination of variables (Table 1). The variables and levels were selected on the basis of the previously single factor experiments performed by Zhu \& Fu (2012). CCD (Table 2) was arranged to allow the design of an appropriate regression model. Six replicates (treatments 4, 5, 7, 10,12, and 20) at the center of the design were used to estimate the error sum of squares. Experiments were randomized to minimize the effects of unexplained variability in the observed responses due to extraneous factors.

The variables were coded according to formula 1 ,

$X_{i}=\frac{x_{i}-\bar{x}_{i}}{\Delta x_{i}}$

where $\mathrm{X}_{\mathrm{i}}$ is the coded value of an independent variable, $\mathrm{x}_{\mathrm{i}}$ is the real value of an independent variable, $\bar{x}_{i}$ is the real value of an independent variable at the central point, and $\Delta \mathrm{x}_{\mathrm{i}}$ is the step change.

\subsection{Preparation of PPI}

The experiments were carried out in a random order of that presented for CCD (Table 2). Defatted perilla seed flour (10 g) was suspended in distilled water at each specific liquid-to-solid ratio. The $\mathrm{pH}$ of the mixture was adjusted to 10 with $0.1 \mathrm{~mol} / \mathrm{L} \mathrm{NaOH}$ using a PHS-25 Model pH-meter (Shanghai Yueping Instrument Co., Ltd, Shanghai, China) at room temperature. Periodically, the $\mathrm{pH}$ was measured again and, when necessary, re-adjusted to 10 . The mixture was subjected to a tunable ultrasonic bath

Table 1. Experimental and coded levels of the independent variables for central composite design.

\begin{tabular}{|c|c|c|c|c|c|c|c|}
\hline \multirow{2}{*}{ Variable } & \multicolumn{2}{|c|}{ Symbols } & \multicolumn{5}{|c|}{ Levels } \\
\hline & Coded & Uncoded & -1.68 & -1 & 0 & 1 & 1.68 \\
\hline Ultrasonic power (W) & $\mathrm{X}_{1}$ & $\mathrm{x}_{1}$ & 115.91 & 150 & 200 & 250 & 284.09 \\
\hline Extraction time $(\min )$ & $\mathrm{X}_{2}$ & $\mathrm{x}_{2}$ & 4.773 & 15 & 30 & 45 & 55.226 \\
\hline Liquid-to-solid ratio (mL/g) & $\mathrm{X}_{3}$ & $\mathrm{x}_{3}$ & 6.636 & 8 & 10 & 12 & 13.363 \\
\hline
\end{tabular}

Table 2. Central composite design arrangement and responses in terms of protein yield, water solubility index (WSI), water absorption capacity (WAC), oil holding capacity (OHC), emulsifying activity (EA) and foaming ability (FA).

\begin{tabular}{|c|c|c|c|c|c|c|c|c|c|}
\hline \multirow{2}{*}{ Exp no. } & \multicolumn{3}{|c|}{ Coded variable level } & \multirow{2}{*}{ Yield $Y_{1}(\%)$} & \multirow{2}{*}{$\mathrm{WSI} \mathrm{Y}_{2}(\%)$} & \multirow{2}{*}{ WAC $\mathrm{Y}_{3}(\%)$} & \multirow{2}{*}{$\begin{array}{c}\mathrm{OHC} \mathrm{Y}_{4} \\
(\mathrm{~g} / \mathrm{g})\end{array}$} & \multirow{2}{*}{$\mathrm{EA} \mathrm{Y}_{5}\left(\mathrm{~m}^{2} / \mathrm{g}\right)$} & \multirow{2}{*}{$\mathrm{FA} \mathrm{Y}_{6}(\%)$} \\
\hline & $\mathrm{X}_{1}$ & $\mathrm{X}_{2}$ & $\mathrm{X}_{3}$ & & & & & & \\
\hline 1 & -1 & -1 & -1 & 22.1 & 54.4 & 2.8 & 0.81 & 56.11 & 52.7 \\
\hline 2 & 1 & -1 & -1 & 19.4 & 50.4 & 3.1 & 1.21 & 63.13 & 65.1 \\
\hline 3 & -1 & 1 & -1 & 22.8 & 52.1 & 2.9 & 1.39 & 64.12 & 60.7 \\
\hline 4 & 1 & 1 & -1 & 20.1 & 49.5 & 3.3 & 1.34 & 59.14 & 57.5 \\
\hline 5 & -1 & -1 & 1 & 19.5 & 53.7 & 2.8 & 0.82 & 56.17 & 52.8 \\
\hline 6 & 1 & -1 & 1 & 23.8 & 50.1 & 3.1 & 1.36 & 63.18 & 65.5 \\
\hline 7 & -1 & 1 & 1 & 20.4 & 52.7 & 2.9 & 1.42 & 64.19 & 60.7 \\
\hline 8 & 1 & 1 & 1 & 24.5 & 49.4 & 3.4 & 1.35 & 59.15 & 57.7 \\
\hline 9 & -1.68 & 0 & 0 & 19.1 & 55.5 & 2.8 & 0.83 & 58.01 & 54.8 \\
\hline 10 & 1.68 & 0 & 0 & 25.2 & 49.1 & 2.9 & 1.13 & 61.11 & 59.6 \\
\hline 11 & 0 & -1.68 & 0 & 20.1 & 55.2 & 2.8 & 0.84 & 59.11 & 52.2 \\
\hline 12 & 0 & 1.68 & 0 & 25.6 & 50.1 & 2.9 & 0.93 & 60.04 & 65.1 \\
\hline 13 & 0 & 0 & -1.68 & 18.1 & 50.7 & 3.5 & 1.54 & 59.12 & 62.7 \\
\hline 14 & 0 & 0 & 1.68 & 24.3 & 51.2 & 3.6 & 1.56 & 59.11 & 62.3 \\
\hline 15 & 0 & 0 & 0 & 25.1 & 57.7 & 3.6 & 1.93 & 60.11 & 63.7 \\
\hline 16 & 0 & 0 & 0 & 25.2 & 56.2 & 3.7 & 1.86 & 60.13 & 61.4 \\
\hline 17 & 0 & 0 & 0 & 26.4 & 56.4 & 3.6 & 1.78 & 61.06 & 64.1 \\
\hline 18 & 0 & 0 & 0 & 24.1 & 55.1 & 3.5 & 1.71 & 60.03 & 62.4 \\
\hline 19 & 0 & 0 & 0 & 27.3 & 55.3 & 3.4 & 1.65 & 60.08 & 65.1 \\
\hline 20 & 0 & 0 & 0 & 26.2 & 54.2 & 3.4 & 1.54 & 59.06 & 60.6 \\
\hline
\end{tabular}


(TH-400BQG, 220V and 50Hz Tianhua Ultrasonic Electronic Equipment Co., Beijing, China) at $30^{\circ} \mathrm{C}$, at different power levels and for different extraction time periods. Following extraction, the mixture was centrifuged at 2,000 g for $20 \mathrm{~min}$, and the resulting supernatant was acidified to $\mathrm{pH} 4.5$ with $2 \mathrm{~mol} / \mathrm{L}$ $\mathrm{HCl}$. Following a 30-min incubation at room temperature, precipitated proteins were collected by centrifugation under the same conditions as previously described and freeze dried in a Scientz-N model freeze-dryer (Ningbo Scientz Biotechnology Co., Ltd, Ningbo, China).

\subsection{Determination of dependent variables}

Protein yield

PPI yield (\%) was calculated using formula 2,

$\operatorname{Yied}(\%)=\frac{p}{s} \times 100 \%$

where $p$ is the weight (g) of the extracted and freeze-dried protein powder, and $s$ is the weight $(\mathrm{g})$ of defatted perilla seed flour after extraction.

\section{Water solubility index and water absorption capacity}

Water solubility index (WSI) and water absorption capacity (WAC) were determined by the method reported by Obilana et al. (2014) with some modifications. Freeze-dried samples $\left(0.2 \mathrm{~g}, M_{0}\right)$ were suspended in $20 \mathrm{~mL}$ of $0.1 \mathrm{~mol} / \mathrm{L}$ phosphate buffer $(\mathrm{pH} 7)$ and mixed for $30 \mathrm{~min}$ at room temperature. The $\mathrm{pH}$ of the suspensions was measured and adjusted when necessary. The suspensions were centrifuged at 2,000 $\mathrm{g}$ for $30 \mathrm{~min}$. The resulting sediment was weighted $\left(M_{2}\right)$ and dried at $100^{\circ} \mathrm{C}$ for $24 \mathrm{~h}$, and the dried weight $\left(M_{1}\right)$ was determined. WSI and WAC were calculated using formulas 3 and 4 , respectively,

$$
\begin{gathered}
W S I=\frac{\left(M_{0}-M_{1}\right) \times 100}{M_{0}} \\
W A C=\frac{\left(M_{2}-M_{1}\right) \times 100}{M_{0}}
\end{gathered}
$$

\section{Oil holding capacity}

Oil holding capacity (OHC) was determined by the method reported by Mundi \& Aluko (2012) with some modifications. Protein sample ( $3 \mathrm{~g}$ ) was dispersed in $25 \mathrm{~mL}$ pure canola oil in a $50-\mathrm{mL}$ pre-weighed centrifuge tube, vortexed for $1 \mathrm{~min}$, allowed to stand for $30 \mathrm{~min}$, and centrifuged at 2,000 g for $20 \mathrm{~min}$ at room temperature. The separated oil was removed with a pipette, and the tubes were inverted for $25 \mathrm{~min}$ to drain the oil prior to reweighing. OHC was expressed as grams of oil bound per gram of sample (dry basis).

\section{Emulsion activity}

Emulsion activity (EA) was determined by the method reported by Zhao et al. (2011) with minor modifications. For the formation of an emulsion, $9 \mathrm{~mL}$ of $0.1 \%(\mathrm{w} / \mathrm{v})$ protein solution $(\mathrm{pH} 7)$ was mixed with $3 \mathrm{~mL}$ pure canola oil for $60 \mathrm{~s}$ in a high-speed homogenizer (XHF-DY, Ningbo Scientz Biotechnology Co., Ltd.
Ningbo, China) at 1,500 g. Subsequently, $50 \mu \mathrm{L}$ of emulsion was immediately transferred to a test tube containing $5 \mathrm{~mL}$ of $0.1 \%$ SDS (w/v). Absorbance was measured in a UV-spectrophotometer (UV-8000S, Shanghai Metash Instrument Co., Ltd., Shanghai, China) at $500 \mathrm{~nm}$. EA was calculated using formula 5 ,

$E A\left(m^{2} / g\right)=\frac{2 \times 2.303 \times A \times D}{C \times \varphi \times \theta \times 10000}$

where $C$ is the initial concentration of protein $(\mathrm{g} / \mathrm{mL}), \varphi$ is the optical path $(1 \mathrm{~cm}), \theta$ is the oil volume fraction used to form the emulsion (0.25), $D$ is the dilution factor (100), and $A$ is the absorbance of the diluted emulsions. Measurements were performed in triplicate.

\section{Foaming ability}

Foaming ability (FA) was determined according to the methods reported by Shahidi et al. (1995) and Tsutsui (1988) with some modifications. In this experiment, $20 \mathrm{~mL}$ of $3 \%(\mathrm{w} / \mathrm{v})$ aqueous sample dispersions were homogenized at 2,000 $\mathrm{g}$ for $1 \mathrm{~min}$, and the resulting foam was immediately transferred into a graduated cylinder. The volume was recorded before and after foam formation. FA was expressed as the increase in volume (\%) due to whipping and was calculated using formula 6 ,

$F A=\frac{\left(V_{2}-V_{1}\right) \times 100}{V_{1}}$

where $V_{1}$ is the initial volume of solution, and $V_{2}$ is the volume of solution after whipping.

\subsection{Statistical analysis}

A multiple regression equation was used to fit the second-order polynomial equation shown in formula 7 ,

$Y_{i}=\beta_{0}+\beta_{1} X_{1}+\beta_{2} X_{2}+\beta_{3} X_{3}+\beta_{11} X_{1}^{2}+$

$\beta_{22} X_{2}^{2}+\beta_{33} X_{3}^{2}+\beta_{12} X_{1} X_{2}+\beta_{13} X_{1} X_{3}+\beta_{23} X_{2} X_{3}$

where $Y_{\mathrm{i}}(\mathrm{i}=1-6)$ is the predicted response for protein yield, WSI, WAC, OHC, EA, and FA of protein concentrate; $\beta_{0}$ is the value of the fitted response at the central point of the design; $\beta_{1}, \beta_{2}$, and $\beta_{3}$ are linear terms; $\beta_{12}, \beta_{13}$, and $\beta_{23}$ represent interaction effects; and $\beta_{11}, \beta_{22}$, and $\beta_{33}$ are squared effects. All experiments were performed in triplicate and in random order. The experimental data are presented in Table 2. Statistical analysis was performed using the software Stat-Ease Design-Expert 8.0.6.1 Trial computer program (Stat-Ease Inc., Minneapolis, MN, USA). The analysis of variance (ANOVA) and Tukey tests were used for the checking of the statistical significance with confidence level of $95.0 \%$. The ANOVA produced parameters; lack of fit, coefficient of determination $\left(\mathrm{R}^{2}\right)$ and F-test were employed to evaluate the model adequacy (Hayta \& İş̧imen, 2017). The model was fitted by multiple linear regressions and response surface plots were obtained for six responses.

\subsection{Thermal properties}

The thermal properties of PPI obtained under optimum conditions and of perilla protein extracted by conventional methods (Li et al., 2013) were assessed by differential scanning 
calorimetry (DSC) using a TA Q100-DSC thermal analyzer (TA Instruments, New Castle, DE, USA). Approximately 2-3 mg protein was accurately weighed into aluminum pans. The pans were hermetically sealed and heated from $20^{\circ} \mathrm{C}$ to $120^{\circ} \mathrm{C}$ at $5{ }^{\circ} \mathrm{C} / \mathrm{min}$. A sealed empty pan was used as reference. Onset $\left(T_{\mathrm{m}}\right)$ and peak $\left(T_{\mathrm{d}}\right)$ denaturation temperatures and enthalpy of denaturation $(\Delta H)$ were computed from the thermograms by the Universal Analysis 2000, version 4.1D software (TA Instruments-Waters LLC, USA).

\subsection{Sodium dodecyl sulfate polyacrylamide gel electrophoresis (SDS-PAGE)}

The polypeptide profiles of PPI and SPI were analyzed by SDS-PAGE, using $12.5 \%$ separating gel and 5\% stacking gel (Brunelle \& Green, 2014). The protein samples were dissolved in $0.5 \mathrm{~mol} / \mathrm{L}$ Tris- $\mathrm{HCl}$ buffer ( $\mathrm{pH}$ 6.8), containing 10\% SDS, $2.5 \%$ 2 -mercaptoethanol, and $1 \%$ bromophenol blue, resulting in a final protein concentration of $1 \mathrm{mg} / \mathrm{mL}$. The mixture was heated in boiling water for $3 \mathrm{~min}$ and centrifuged at $5000 \mathrm{~g}$ for $5 \mathrm{~min}$. For each sample, $15 \mu \mathrm{L}$ of supernatant was loaded into each well. Electrophoresis was performed at a constant current of $15 \mathrm{~mA}$ in the stacking gel and $25 \mathrm{~mA}$ in the separating gel until the tracking dye reached the bottom of the gel. Following electrophoresis, the gel was stained for $3 \mathrm{~h}$ with $0.25 \%$ Coomassie blue (R-250) in acetic acid/methanol/water solution (46:227:227, v/v/v) and subsequently destained for $6 \mathrm{~h}$ with methanol/acetic acid / water solution $(2: 3: 35, \mathrm{v} / \mathrm{v} / \mathrm{v})$.

\section{Results and Discussion}

\subsection{Fitting the mathematical model}

Multiple regression equations were generated between the predicted responses $\left(\mathrm{Y}_{1}, \mathrm{Y}_{2}, \mathrm{Y}_{3}, \mathrm{Y}_{4}, \mathrm{Y}_{5}\right.$, and $\left.\mathrm{Y}_{6}\right)$ and the three variables, i.e., ultrasonic power, extraction time, and liquid-to-solid ratio (Table 2 ). The regression coefficients (Table 3 ) were determined by the least squares technique, and the appropriate subset of variables for the regression model was determined by the backward elimination technique (Kleijnen, 2008).

The significance of the coefficients in the models was determined by analysis of variance (Table 3 ). The results revealed that protein yield $\left(\mathrm{Y}_{1}\right)$ and $\mathrm{FA}\left(\mathrm{Y}_{6}\right)$ were significant at $p<0.01$, and WSI $\left(\mathrm{Y}_{2}\right)$, WAC $\left(\mathrm{Y}_{3}\right), \mathrm{OHC}\left(\mathrm{Y}_{4}\right)$, and EA $\left(\mathrm{Y}_{5}\right)$ were significant at $p<0.001$. The coefficient of determination $\left(\mathrm{R}^{2}\right)$ of the model was high $(>0.823)$. Therefore, the experimental values matched the model-predicted values. According to Man et al. (2010), a model is adequate when $\mathrm{R}^{2}>0.75$. Lack-of-fit measures the failure of a model to represent the data in the experimental domain at points that are not included in the regression. As shown in Table 3, the lack-of-fit for all fitted models was non-significant $(p>0.05)$. Therefore, the quadratic model adequately represented the data for all responses.

\subsection{Response surface plotting}

\section{Protein yield}

PPI yield was affected by ultrasonic power and liquid-tosolid ratio. The linear effect of ultrasonic power and liquidto-solid ratio was positive and significant at $p<0.05$, and the interaction between these two variables was positive and significant at $p<0.05$. On the other hand, extraction time had a negligible effect on PPI yield (Table 3). Figure 1A shows the effect of ultrasonic power and liquid-to-solid ratio on protein yield at a constant extraction time $(30 \mathrm{~min})$. Protein yield had a non-significant increase with increasing ultrasonic power and liquid-to-solid ratio at low ultrasonic power and liquid-to-solid ratios. However, at high ultrasonic power and liquid-to-solid ratios, protein yield increased with increasing ultrasonic power and liquid-to-solid ratio. These results could be attributed to increased protein decomposition at high ultrasonic power and increased cavitation effects at high liquid-to-solid ratios. In this

Table 3. Coefficients and analysis of variance for the fitted models.

\begin{tabular}{|c|c|c|c|c|c|c|c|}
\hline & \multicolumn{2}{|r|}{ Yield } & WSI & WAC & $\mathrm{OHC}$ & EA & FA \\
\hline$\beta_{0}$ & \multicolumn{2}{|r|}{25.69} & 55.70 & 3.54 & 1.74 & 60.11 & 62.87 \\
\hline$\beta_{1}$ & \multicolumn{2}{|r|}{$0.99^{\mathrm{a}}$} & $-1.78^{c}$ & $0.10^{\mathrm{b}}$ & $0.097^{\mathrm{a}}$ & $0.68^{\mathrm{a}}$ & $1.96^{\mathrm{a}}$ \\
\hline$\beta_{2}$ & \multicolumn{2}{|r|}{0.90} & $-1.01^{\mathrm{b}}$ & $0.076^{\mathrm{a}}$ & $0.11^{\mathrm{a}}$ & $0.70^{\mathrm{a}}$ & $1.64^{\mathrm{a}}$ \\
\hline$\beta_{3}$ & \multicolumn{2}{|r|}{$1.07^{\mathrm{a}}$} & 0.037 & $3.195 \mathrm{E}-003$ & 0.017 & 0.013 & 0.016 \\
\hline$\beta_{12}$ & \multicolumn{2}{|r|}{-0.024} & 0.22 & 0.044 & -0.13 & $-3.01^{c}$ & $-3.92^{b}$ \\
\hline$\beta_{13}$ & \multicolumn{2}{|r|}{$1.73^{\mathrm{a}}$} & -0.041 & 0.014 & 0.015 & $-8.75 \mathrm{E}-003$ & 0.048 \\
\hline$\beta_{23}$ & \multicolumn{2}{|r|}{$-3.75 \mathrm{E}-003$} & 0.17 & -0.014 & -0.015 & $-3.75 \mathrm{E}-003$ & -0.04 \\
\hline$\beta_{11}$ & \multicolumn{2}{|r|}{$-1.30^{\mathrm{a}}$} & $-1.25^{b}$ & $-0.24^{c}$ & $-0.25^{c}$ & & $-2.02^{\mathrm{a}}$ \\
\hline$\beta_{22}$ & \multicolumn{2}{|r|}{$-1.07^{\mathrm{a}}$} & $-1.13^{b}$ & $-0.24^{c}$ & $-0.28^{c}$ & & $-1.51^{\mathrm{a}}$ \\
\hline \multirow[t]{3}{*}{$\beta_{33}$} & \multicolumn{2}{|r|}{$-1.65^{b}$} & $-1.72^{c}$ & $-6.913 \mathrm{E}-003$ & -0.046 & & -0.14 \\
\hline & \multirow{2}{*}{$\mathrm{df}$} & \multicolumn{6}{|c|}{ Sum of squares } \\
\hline & & Yield & WSI & WAC & $\mathrm{OHC}$ & EA & FA \\
\hline Model & 9 & $131.4^{\mathrm{b}}$ & $128.65^{c}$ & $1.80^{c}$ & $2.27^{\mathrm{c}}$ & $85.24^{c}$ & $296.74^{\mathrm{b}}$ \\
\hline Lack of fit & 5 & $18.61^{\mathrm{d}}$ & $3.30^{\mathrm{d}}$ & $0.079^{\mathrm{d}}$ & $0.11^{\mathrm{d}}$ & $7.81^{\mathrm{d}}$ & $48.99^{\mathrm{d}}$ \\
\hline Pure error & 5 & 6.50 & 5.46 & 0.065 & 0.10 & 2.01 & 14.79 \\
\hline Total & 19 & 156.51 & 137.42 & 1.94 & 2.47 & 95.07 & 360.52 \\
\hline $\mathrm{R}^{2}$ & & 0.839 & 0.936 & 0.926 & 0.916 & 0.896 & 0.823 \\
\hline
\end{tabular}

a Significant at $p<0.05$; ${ }^{\mathrm{b}}$ Significant at $p<0.01$; ' Significant at $p<0.001$; ${ }^{\mathrm{d}}$ Non-significant. 
study, PPI yield was higher than that reported by Zhu \& Fu (2012) in perilla seed meal proteins (11.77\%).

\section{Water solubility index}

Protein WSI is the most important functional property because it affects other functional properties. In several protein-based formulations such as emulsions and foams, optimal protein solubility is required. Table 3 shows that ultrasonic power and extraction time had a negative effect on WSI $(p<0.01)$, whereas liquid-to-solid ratio had a weak effect on WSI. The interaction between ultrasonic power and extraction time had a non-significant effect on WSI. Figure 1B shows the effect of ultrasonic power and extraction time on WSI at a constant liquid-to-solid ratio $(7: 1)$. WSI decreased with increasing ultrasonic power and extraction time, probably due to protein denaturation, exposure of buried hydrophobic groups, and protein aggregation. In this study, PPI solubility was similar to that reported in peanut protein concentrate $(>40 \%)$ by Wu et al. (2009) and higher than that obtained in cowpea protein concentrate $(<20 \%)$ by Mune Mune et al. (2014).
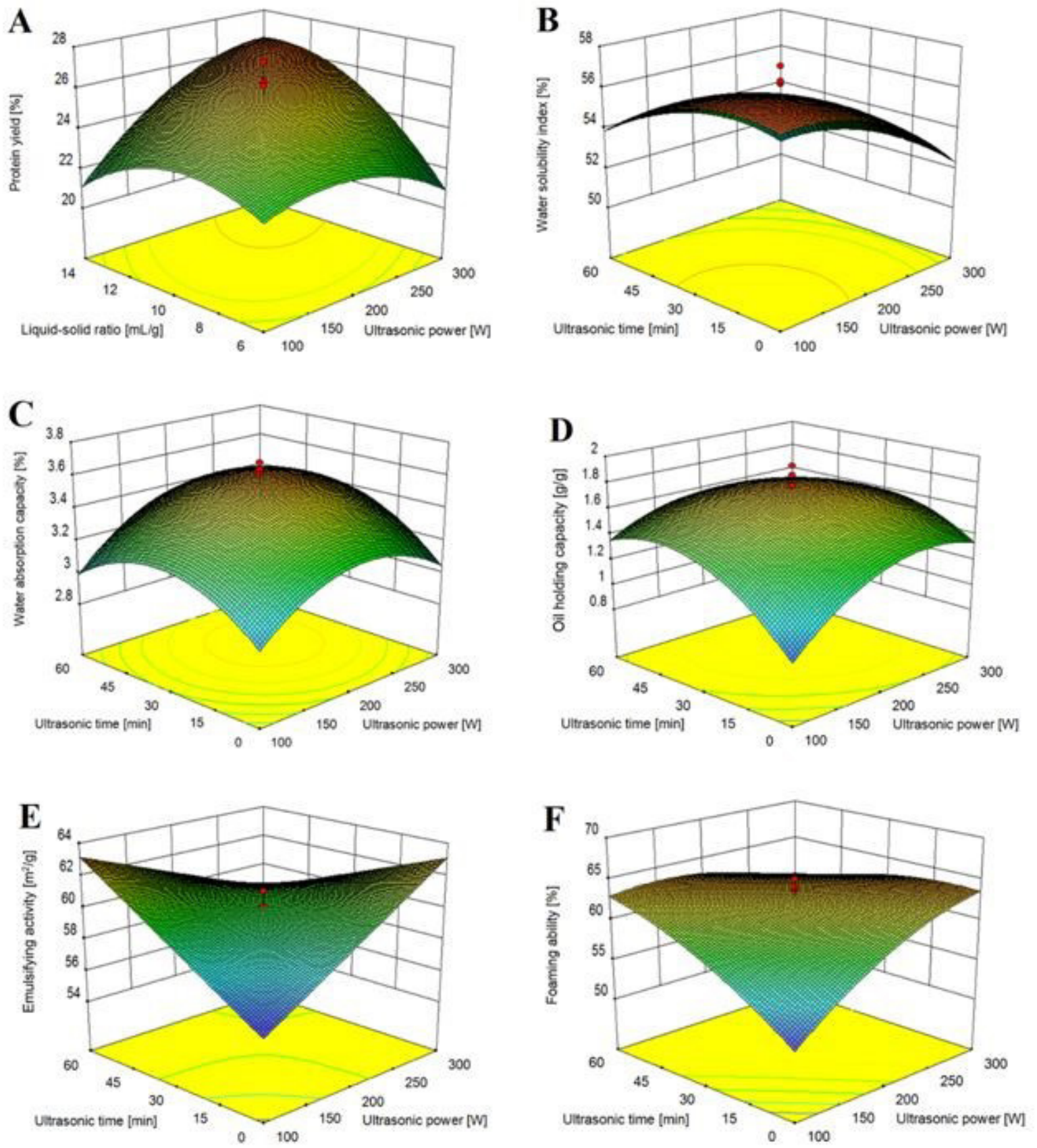

Figure 1. The effect of ultrasonic power, extraction time, and liquid-to-solid ratio on protein yield (A), water solubility index (B), water absorption capacity (C), oil holding capacity (D), emulsifying activity (E), and foaming ability (F) of perilla protein isolate. 


\section{Water absorption capacity}

Protein WAC was affected by ultrasonic power $(p<0.01)$ and extraction time $(p<0.05)$. Liquid-to-solid ratio had a weak effect on WAC. The interaction between ultrasonic power and extraction time had a non-significant effect on WAC (Table 3). Figure 1C shows the effect of ultrasonic power and extraction time on WAC at a constant liquid-to-solid ratio (7:1). WAC increased with ultrasonic power and extraction time up to $3.56 \mathrm{~g} / \mathrm{g}$ and decreased thereafter (Figure 1C). The highest WAC level was achieved at an ultrasonic power coded level of 0.24 (212 W uncoded) and an extraction time coded level of 0.17 (32.55 min uncoded). In this study, WAC of PPI was higher than that obtained in peanut protein concentrates and isolates (1.2-2.7 g/g) (Wu et al., 2009). Kinsella (1979) reported that the major factors affecting WAC include protein denaturation/unfolding and the presence of carbohydrates and non-protein components. During extraction, PPI was likely denatured, exposing hydrophobic sites, which explained the reduced water retention.

\section{Oil holding capacity}

High OHC is desirable in the cold meat industry, particularly in sausage production (Ogunwolu et al., 2009). Ultrasonic power, extraction time, and the interaction between these two variables had significant effects on $\mathrm{OHC}(p<0.05)$. Liquid-to-solid ratio had a weak effect on OHC (Table 3 ). Figure 1D shows the effect of ultrasonic power and extraction time on $\mathrm{OHC}$ at a constant liquid-to-solid ratio (7:1). At low ultrasonic power, $\mathrm{OHC}$ increased with increasing extraction time, while at high ultrasonic power, $\mathrm{OHC}$ decreased with increasing extraction time. PPI OHC was similar to that reported by Mune Mune et al. (2014) for cowpea protein concentrate $(1.75 \mathrm{~g} / \mathrm{g})$, and higher than that reported by Boye et al. (2010) for pea protein isolate $(\sim 1.2 \mathrm{~g} / \mathrm{g})$. Ultrasound affected the physical entrapment of oil and the non-covalent bonds involved in lipid-protein interactions, thereby modifying $\mathrm{OHC}$.

\section{Emulsifying activity}

Table 3 shows that ultrasonic power, extraction time, and the interaction between these two variables had a significant effect on EA $(p<0.05)$. Liquid-to-solid ratio had a weak effect on EA. Figure 1E shows the effect of ultrasonic power and extraction time on EA at a constant liquid-to-solid ratio $(7: 1)$. At low ultrasonic power and extraction time, EA increased with increasing ultrasonic power and time. At high ultrasonic power and extraction time, EA decreased with increasing ultrasonic power and time. Proteins are effective emulsifiers that are commonly used in food emulsions. The formation and stability of protein-based emulsions are related to the surface activity of proteins at interfaces (Lam \& Nickerson, 2013). In this study, high EA values could be attributed to protein denaturation and exposure of hydrophobic amino acids, which facilitated protein interaction at the oil-water interface.

\section{Foaming ability}

FA was affected by ultrasonic power and extraction time (Table 3; $p<0.05$ ). The interaction between ultrasonic power and extraction time had a significant effect on FA $(p<0.01)$, whereas liquid-to-solid ratio had a weak effect. Figure $1 \mathrm{~F}$ shows the effect of ultrasonic power and extraction time on FA at a constant liquid-to-solid ratio (7:1). At low ultrasonic power and extraction time, FA increased with increasing ultrasonic power and extraction time, while at high ultrasonic power and extraction time, FA decreased with increasing ultrasonic power and extraction time. FA of PPI was similar to that reported by Mune Mune et al. (2014) in cowpea protein concentrate (> 60\%). Therefore, PPI represents a good foaming agent and may be suitable in bakery goods and ice cream. Ultrasound enhances protein unfolding and the formation of interfacial protein membranes at the air-water interface, which enhances air bubble encapsulation.

\subsection{Optimization}

The regression model equation allowed the prediction of the effects of the three variables on the six responses, and RSM was performed to optimize the three variables. The optimum conditions and predicted responses are presented in Table 4. For convenience, the optimum conditions were slightly modified to an ultrasonic power of $200 \mathrm{~W}$, an extraction time of $32 \mathrm{~min}$, and a liquid-to-solid ratio of 10 . The experimental values were in agreement with the predicted values. The extraction conditions obtained by RSM were accurate, reliable, and practical (Xu et al., 2013).

\subsection{Thermal properties}

The thermal properties of PPI were evaluated by DSC (Table 5). Li-Chan \& Ma (2002) reported that DSC endothermic peaks are indicative of protein denaturation. PPI had a weak DSC endothermic peak $(0.03 \mathrm{~J} / \mathrm{g})$ suggesting that several components

Table 4. Optimum conditions, predicted, and experimental values of response at optimum conditions.

\begin{tabular}{|c|c|c|c|}
\hline \multicolumn{2}{|c|}{ Optimum condition } & Coded levels & Actual levels \\
\hline \multicolumn{2}{|c|}{ Ultrasonic power } & 0.12 & 206 \\
\hline \multicolumn{2}{|c|}{ Extraction time } & 0.16 & 32.4 \\
\hline \multicolumn{2}{|c|}{ Liquid-to-solid ratio } & 0.17 & 10.34 \\
\hline \multirow{2}{*}{ Responses } & \multirow{2}{*}{ Predicted value } & \multicolumn{2}{|c|}{ Experimental value $^{\mathrm{a}}$} \\
\hline & & Mean & Range \\
\hline Yield (\%) & 26.1 & $26.7 \pm 0.03$ & $25.1-27.2$ \\
\hline WSI (\%) & 55.2 & $56.1 \pm 0.15$ & $55.2-56.8$ \\
\hline WAC (\%) & 3.6 & $3.3 \pm 0.01$ & $3.1-3.5$ \\
\hline $\mathrm{OHC}(\mathrm{g} / \mathrm{g})$ & 1.76 & $1.47 \pm 0.02$ & $1.21-1.67$ \\
\hline $\mathrm{EA}\left(\mathrm{m}^{2} / \mathrm{g}\right)$ & 60.25 & $61.13 \pm 0.10$ & $60.08-62.56$ \\
\hline FA (\%) & 63.2 & $62.7 \pm 0.11$ & $61.3-63.7$ \\
\hline
\end{tabular}

${ }^{a}$ Mean of three determinations.

Table 5. Thermal properties of perilla protein isolate (PPI).

\begin{tabular}{crc}
\hline & PPI & $\begin{array}{c}\text { The contrast perilla } \\
\text { protein }\end{array}$ \\
\hline$T_{\mathrm{m}}\left({ }^{\circ} \mathrm{C}\right)$ & $69.61 \pm 0.11$ & $52.35 \pm 0.13$ \\
$T_{\mathrm{d}}\left({ }^{\circ} \mathrm{C}\right)$ & $75.16 \pm 0.21$ & $67.24 \pm 0.41$ \\
$\Delta H(\mathrm{~J} / \mathrm{g})$ & $0.03 \pm 0.10$ & $1.31 \pm 0.16$ \\
\hline
\end{tabular}

All the data are expressed as mean \pm SD and are the mean of three replicates within the same line denote that are significantly different $(p<0.05) ; T_{\mathrm{m}}$ : temperature onset; $T_{\mathrm{d}}$ : denaturation temperature; $\Delta H$ : enthalpy of denaturation. 
in PPI were denatured and unfolded, and that ultrasound had a negative effect on the structure. Denaturation temperature $\left(T_{\mathrm{d}}\right)$ is an indicator of the thermal stability of proteins (Amza et al., 2011). $T_{d}$ was $75.16^{\circ} \mathrm{C}$ in PPI and $67.24^{\circ} \mathrm{C}$ in perilla protein extracted using alkali and acidic solutions. Therefore, PPI was more thermo-stable than perilla protein. This result might be attributed to the ultrasound disruption of intermolecular bonds in PPI. Ghribi et al. (2015) reported that the structural transitions of protein originating from hydrolyzed peptide bonds during extraction may be responsible for the changes observed in DSC.

\subsection{SDS-PAGE}

Variations in polypeptide profiles of proteins have direct effects on their functional properties, especially on EA and FA (Mundi \& Aluko, 2012). SDS-PAGE was performed to determine the molecular weight of PPI. SPI was run on the gels as a control. Pictures of SDS-PAGE gels are shown in Figure 2. PPI (lane 1) exhibited major bands at 14.4-66.2 kDa. Marcone et al. (2002) reported that bands at 20-27 and 30-39 kDa represent basic and acidic protein subunits, respectively. Therefore, PPI was rich in both types of subunits.

As observed in the gel patterns, PPI and SPI fractions had relatively different polypeptide composition profiles. PPI had eight polypeptides $(66.2,45,36,34,33,30,22$, and $14.4 \mathrm{kDa})$ with the $14.4 \mathrm{kDa}$ band in the highest proportion, while SPI

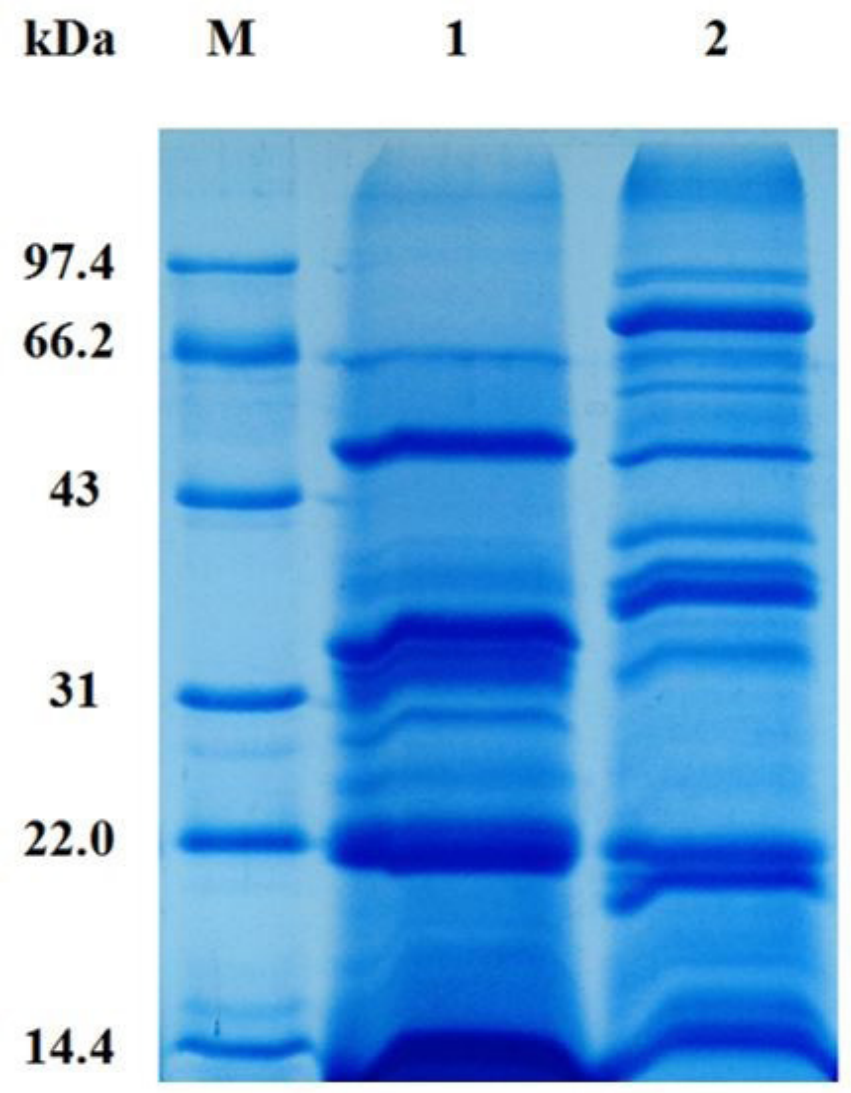

Figure 2. SDS-PAGE profiles of perilla protein isolate (PPI) and soy protein isolate (SPI). Lane M: low molecular weight standard protein marker, lane 1: PPI, lane 2: SPI. had thirteen bands $(97,80,66.2,65,44,41,39,38,34,22,20$, 16 , and $15 \mathrm{kDa}$ ) with the $80 \mathrm{kDa}$ in the highest proportion. The polypeptide molecular weight range of PPI was lower than that of SPI. Consequently, the solubility of PPI is predicted to be better than that of SPI.

\section{Conclusion}

RSM was successfully applied to model and optimize PPI reparation. Protein yield was significantly affected by ultrasonic power and liquid-to-solid ratio. WSI, WAC, OHC, EA, and FA were affected by ultrasonic power and extraction time. The interaction between ultrasonic power and liquid-to-solid ratio was significant for protein yield, and the interaction between ultrasonic power and extraction time was significant for OHC, EA, and FA. The optimum PPI extraction conditions consisted of an ultrasonic a power of $200 \mathrm{~W}$, an extraction time of $32 \mathrm{~min}$, and a liquid-to-solid ratio of 10 . Under these conditions, the predicted protein yield and functional properties were in agreement with the experimental values. This study demonstrated that PPI had optimal functional properties and thermal stability. PPI subunits had molecular weights that ranged between 14.4 and $66.2 \mathrm{kDa}$. PPI could be applied in functional foods and as a potential food ingredient.

\section{References}

Amza, T., Amadou, I., Zhu, K. X., \& Zhou, H. M. (2011). Effect of extraction and isolation on physicochemical and functional properties of an underutilized seed protein: Gingerbread plum (Neocarya macrophylla). Food Research International, 44(9), 2843-2850. http:// dx.doi.org/10.1016/j.foodres.2011.06.029.

Asif, M. (2011). Health effects of omega-3,6,9 fatty acids: Perilla frutescens is a good example of plant oils. Oriental Pharmacy and Experimental Medicine, 11(1), 51-59. PMid:21909287. http://dx.doi. org/10.1007/s13596-011-0002-X.

Azmir, J., Zaidul, I. S. M., Rahman, M. M., Sharif, K. M., Sahena, F., Jahurul, M. H. A., \& Mohamed, A. (2014). Optimization of oil yield of Phaleria macrocarpa seed using response surface methodology and its fatty acids constituents. Industrial Crops and Products, 52, 405-412. http://dx.doi.org/10.1016/j.indcrop.2013.11.009.

Boye, J. I., Aksay, S., Roufik, S., Ribéreau, S., Mondor, M., Farnworth, E., \& Rajamohamed, S. H. (2010). Comparison of the functional properties of pea, chickpea and lentil protein concentrates processed using ultrafiltration and isoelectric precipitation techniques. Food Research International, 43(2), 537-546. http://dx.doi.org/10.1016/j. foodres.2009.07.021.

Brunelle, J. L., \& Green, R. (2014). One-dimensional SDS-polyacrylamide gel electrophoresis (1D SDS-PAGE). Methods in Enzymology, 541, 151-159. PMid:24674069. http://dx.doi.org/10.1016/B978-0-12420119-4.00012-4.

Ghribi, A. M., Gafsi, I. M., Sila, A., Blecker, C., Danthine, S., Attia, H., Bougatef, A., \& Besbes, S. (2015). Effects of enzymatic hydrolysis on conformational and functional properties of chickpea protein isolate. Food Chemistry, 187, 322-330. PMid:25977033. http://dx.doi. org/10.1016/j.foodchem.2015.04.109.

Hayta, M., \& İşçimen, E. M. (2017). Optimization of ultrasound-assisted antioxidant compounds extraction from germinated chickpea using response surface methodology. Lebensmittel-Wissenschaft + Technologie, 77, 208-216. http://dx.doi.org/10.1016/j.lwt.2016.11.037. 
Karnopp, A. R., Figueroa, A. M., Los, P. R., Teles, J. C., Simões, D. R. S., Barana, A. C., Kubiaki, F. T., Oliveira, J. G. B., \& Granato, D. (2015). Effects of whole-wheat flour and bordeaux grape pomace (Vitis labrusca L.) on the sensory, physicochemical and functional properties of cookies. Food Science and Technology, 35(4), 750-756. http://dx.doi.org/10.1590/1678-457X.0010.

Kinsella, J. E. (1979). Functional properties of soy proteins. Journal of the American Oil Chemists' Society, 56(3), 242-258. http://dx.doi. org/10.1007/BF02671468.

Kleijnen, J. P. C. (2008). Response surface methodology for constrained simulation optimization: an overview. Simulation Modelling Practice and Theory, 16(1), 50-64. http://dx.doi.org/10.1016/j.simpat.2007.10.001.

Lam, R. S. H., \& Nickerson, M. T. (2013). Food proteins: a review on their emulsifying properties using a structure-function approach. Food Chemistry, 141(2), 975-984. PMid:23790876. http://dx.doi. org/10.1016/j.foodchem.2013.04.038.

Li, X. P., Zhang, Z. J., \& Li, H. Z. (2013). Optimization of protein extraction technology from perilla meal. China Oils and Fats, 38, 33-35. http://dx.doi.org/10.3969/j.issn.1003-7969.2013.02.009.

Li-Chan, E. C. Y., \& Ma, C.-Y. (2002). Thermal analysis of flaxseed (Linum usitatissimum) proteins by differential scanning calorimetry. Food Chemistry, 77(4), 495-502. http://dx.doi.org/10.1016/S03088146(01)00365-X.

Longvah, T., \& Deosthale, Y. G. (1991). Chemical and nutritional studies on hanshi (perilla frutescens), a traditional oilseed from northeast india. Journal of the American Oil Chemists' Society, 68(10), 781-784. http://dx.doi.org/10.1007/BF02662172.

Longvah, T., \& Deosthale, Y. G. (1998). Effect of dehulling, cooking and roasting on the protein quality of Perilla frutescens seed. Food Chemistry, 63(4), 519-523. http://dx.doi.org/10.1016/S03088146(98)00030-2.

Luque-García, J. L., \& Castro, M. D. L. D. (2003). Ultrasound: a powerful tool for leaching. TrAC Trends in Analytical Chemistry, 22, 41-47.

Man, H. L., Behera, S. K., \& Park, H. S. (2010). Optimization of operational parameters for ethanol production from korean food waste leachate. International Journal of Environmental Science and Technology, 7(1), 157-164. http://dx.doi.org/10.1007/BF03326127.

Marcone, M. R., Kakuda, Y., Jahaniaval, F., Yada, R. Y., \& Montevirgen, L. S. (2002). Characterization of the proteins of Pili nut (Canarium ovatum, Engl.). Plant Foods for Human Nutrition, 57(2), 107-120. PMid:12049143. http://dx.doi.org/10.1023/A:1015266423254.

Mundi, S., \& Aluko, R. E. (2012). Physicochemical and functional properties of kidney bean albumin and globulin protein fractions. Food
Research International, 48(1), 299-306. http://dx.doi.org/10.1016/j. foodres.2012.04.006.

Mune Mune, M. A., Minka, S. R., \& Mbome, I. L. (2014). Optimising functional properties during preparation of cowpea protein concentrate. Food Chemistry, 154, 32-37. PMid:24518312. http:// dx.doi.org/10.1016/j.foodchem.2013.12.108.

Obilana, A. O., Odhav, B., \& Jideani, V. A. (2014). Functional and physical properties of instant beverage powder made from two different varieties of Pearl Millet. Journal of Food and Nutrition Research, 2(5), 250-257. http://dx.doi.org/10.12691/jfnr-2-5-7.

Ogunwolu, S. O., Henshaw, F. O., Mock, H. P., Santros, A., \& Awonorin, S. O. (2009). Functional properties of protein concentrates and isolates produced from cashew (Anacardium occidentale L.) nut. Food Chemistry, 115(3), 852-858. http://dx.doi.org/10.1016/j. foodchem.2009.01.011.

Shahidi, F., Han, X. Q., \& Synowiecki, J. (1995). Production and characteristics of protein hydrolysates from capelin (Mallotus villosus). Food Chemistry, 53(3), 285-293. http://dx.doi.org/10.1016/03088146(95)93934-J.

Tsutsui, T. (1988). Functional properties of heat-treated egg yolk low density lipoprotein. Journal of Food Science, 53(4), 1103-1106. http:// dx.doi.org/10.1111/j.1365-2621.1988.tb13539.x.

Vinatoru, M. (2001). An overview of the ultrasonically assisted extraction of bioactive principles from herbs. Ultrasonics Sonochemistry, 8(3), 303-313. PMid:11441615. http://dx.doi.org/10.1016/S13504177(01)00071-2.

Wu, H., Wang, Q., Ma, T., \& Ren, J. (2009). Comparative studies on the functional properties of various protein concentrate preparations of peanut protein. Food Research International, 42(3), 343-348. http:// dx.doi.org/10.1016/j.foodres.2008.12.006.

Xu, Q., Shen, Y., Wang, H., Zhang, N., Xu, S., \& Zhang, L. (2013). Application of response surface methodology to optimise extraction of flavonoids from fructus sophorae. Food Chemistry, 138(4), 2122-2129. PMid:23497866. http://dx.doi.org/10.1016/j.foodchem.2012.11.099.

Zhao, G., Liu, Y., Zhao, M., Ren, J., \& Yang, B. (2011). Enzymatic hydrolysis and their effects on conformational and functional properties of peanut protein isolate. Food Chemistry, 127(4), 1438-1443. http:// dx.doi.org/10.1016/j.foodchem.2011.01.046.

Zhu, J., \& Fu, Q. (2012). Optimization of ultrasound-assisted extraction process of perilla seed meal proteins. Food Science and Biotechnology, 21(6), 1701-1706. http://dx.doi.org/10.1007/s10068-012-0226-7. 